\title{
EJSBS
}

The European Journal of Social \&

Behavioural Science

ISSN: 2301-2218 (ONUNE)
OPEN ACCESS

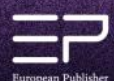

The European Journal of Social and Behavioural Sciences

EJSBS Volume XXX, Issue II (eISSN: 2301-2218)

\section{FOREIGN LANGUAGE TEACHING PRACTICES: ONLINE PROJECTION}

\author{
Elena G. Tareva ${ }^{a *}$ \\ ${ }^{a}$ Moscow City University, 4-1, $2^{\text {nd }}$ Selskokhoziastvenny Proezd, Moscow, Russia
}

\begin{abstract}
Nowadays, educational technologies, in particular, digital means and methods of teaching have become the subject of research studied from different angles. Of interest are educational practices that most successfully disseminate a positive learning experience. The purpose of this paper is to consider the phenomenon of 'best/effective educational practices' and present a set of those that have successfully proven to be effective in teaching foreign languages in a digital environment, in the context of distance learning. The research methods comprised an analysis of existing approaches to productive educational practices, their classification and spheres of application and a survey of 48 experienced higher education teachers followed by the processing and systematization of the data obtained. The research results are an innovative classification of educational practices recommended for teaching foreign languages in a digital environment followed by recommendations for the development of new teaching technologies that can ensure the quality of development of foreign language communicative competence of students.
\end{abstract}

Keywords: Educational practices, digital education, foreign language teaching/learning

(C) 2021 Published by European Publisher. www.europeanpublisher.com

${ }^{*}$ Corresponding author. Tel.: +7-916-321-2393; fax: +7-499-181-2462.

E-mail address: TarevaEG@mgpu.ru

doi: $10.15405 /$ ejsbs.297

This work is licensed under a Creative Commons Attribution-NonCommercial-NoDerivatives 4.0 International License. 
https://doi.org/10.15405/ejsbs.287

eISSN: 2301-2218 / Corresponding Author: Elena G. Tareva

Selection \& Peer-review under responsibility of the Editors

\section{Introduction}

The transition to the post-industrial stage of world development, the digital revolution, new socio-anthropological challenges and postmodern values, the change in basic types of activity and qualifications compounded with the new problems associated with destabilization in the relations between different countries due to the COVID-19 pandemic all require significant changes in the social and behavioural sphere, modernization in different areas of social activity, but above all this, in the sphere of education. In its classical form, the education system, striving for self-preservation, was for a long time characterized by conservatism and consequently, relative closedness, staticity, and inertia. At present, under the influence of a mass of unpredictable and complex integrating factors, this system is rapidly evolving and responding to changes in the surrounding space and demonstrating a readiness for numerous, sometimes unforeseen evolutionary and revolutionary changes.

The new postmodern stage in the development of education presupposes an orientation not so much towards mastering knowledge (which was inherent in the classical 'measurement' of the educational system) as well as the means and operations of performing activities, but also, mainly, towards the explication of goals and values in the field of education and upbringing (Bessarabova et al., 2018; Prabakaran, 2020; Sen et al., 2016; Sterling, 2016; Tarc, 2019). As a result, the educational system is permeated with subjectivity. From operating on a purely rational paradigm, it is transformed into a rational-irrational, variable, multidimensional set of interacting factors. The content of education has acquired axiological characteristics to become spiritually moral, emotionally valuable, and pragmatically charged.

At the same time, the evolving nature of education interacts with virtualization, the large-scale specifics of communications, as well as the anonymity ('avatar') of information and communication practices. Under the influence of these factors, the education system loses the parameters of linearity, closedness, staticity, and conservatism. It is embarking on the path of rapid change, proclaiming innovation and new educational practices as its imperative (Gavrilyuk et al., 2019; Lanzara, 2016; Purtik \& Arenas, 2017; Traube et al., 2016).

\section{Problem Statement}

\subsection{Educational practices: attempts of interpretation}

Educational practice is a relatively new term but has been actively used in social and behavioural sciences publications in recent years, dedicated to the modernization of world education. It can be concluded that the frequency of its use rests on the desire to strengthen the practical orientation of the educational system to emphasize the non-standard characteristics of its post-modern innovative nature by moving away from the traditional generally accepted 
https://doi.org/10.15405/ejsbs.287

eISSN: 2301-2218 / Corresponding Author: Elena G. Tareva

Selection \& Peer-review under responsibility of the Editors

nominations, such as 'educational technologies', 'educational models' and 'educational strategies'.

Today, the educational research and publication environment is replete with references to practices of a different kind - about 'open educational practices' (Panke \& Seufert, 2013; Jhangiani et al., 2019; Makel et al., 2021), 'best practices' (Schuster \& Zingheim, 2013), and 'effective practices' (Penalva, 2019) etc. Obviously, a period has begun for understanding this phenomenon, recognizing its status in the structure of the education system, as well as in relation to specific areas of education, for example, to language teaching and learning.

Best educational practices are understood as "the wide range of individual activities, policies, and programmatic approaches to achieve positive changes in student attitudes or academic behaviors" (Arendale, 2010, p. 2). It is clear that educational practices are reflective of a pragmatic approach to their understanding and evaluation. This conclusion is confirmed by the proposed classification of educational practices (Arendale, 2010, p. 2), which are subdivided into:

- promising education practice: refers to "detailed information describing the education practice with its theoretical basis and how to implement it. Data collection is in process but has not yet completed rigorous evaluation";

- validated education practice: "A promising education practice that has undergone rigorous evaluation documenting positive student outcomes in one education setting. The evaluation design could be experimental or quasi-experimental quantitative, qualitative, or mixed design";

- exemplary education practice: "A validated education practice that has been successfully replicated at multiple education settings with similar positive student outcomes. A similar term used to describe this type of practice by federal Department of Education is "scale-up" since the practice has high potential for wide successful implementation".

This paper raises the question of modern innovative practices of teaching a foreign language, which today, is experiencing a need to enhance the process of influencing the student to master the ability to participate in intercultural dialogue.

\subsection{The features of advanced linguistic education practices}

Several main features make it possible to differentiate linguistic educational practices. The first feature is the obligatory connection between practice and innovation in language education. It is no coincidence that the term 'practice' is often used in publications on innovative vectors in the development of foreign language teaching and learning methods, 
https://doi.org/10.15405/ejsbs.287

eISSN: 2301-2218 / Corresponding Author: Elena G. Tareva

Selection \& Peer-review under responsibility of the Editors

which seems to be related to the need to emphasize the renewal of language education in order to highlight its modern character that is related to today's needs.

The second feature is the result of the work of initiative groups of language teaching innovators who develop new approaches to solving educational problems. At the same time, educational practice can fix the fact of 'personal presence' in the education of the innovators themselves (the phenomenon of participation and the pulsation of subjectivity). Practice demonstrates the students' will to improve their educational level, demostrating their desire to influence the system of foreign language training and education. Thus, educational practice is designed to remove a certain kind of 'anonymity' or 'namelessness' of positive (productive) educational achievements.

The third feature of innovative practice is associated with its mandatory implementation and public recognition. Only that which is socially useful and significant is subject to description and, accordingly, to comprehension. In other words, the development of objectively new experiences is evidenced by its 'living' or its implementation in life (professional) practice. Thus, this category of educational practices would exclude anything that failed to 'influence the masses' or that failed to amass admirers, consumers or followers.

The fourth feature (and this presents the greatest difficulty in understanding and describing the phenomenon) is associated with the variety of educational practices and the resulting complexity in listing, grouping, classification, codification, differentiation, etc. This leads to numerous non-conventional, unrecognized, non-systemic (differing from generally recognized) practices; but, at the same time, in terms of its positive evolution and social recognition, educational practice is approved as normative, losing the flair of irrationality and converting its status from subjective ('useful for me personally') to objective ('useful for everyone').

The fifth feature is associated with the understanding that current educational practices relate to changes in the quality of teaching and the manner of interaction between the subjects of the educational process. It is precisely the change in the quality of teaching and the interaction of those who teach and study that should become the main content of the reforms of the school educational system (Penuel et al., 2020)

Finally, the sixth feature - empirical - presupposes the following formula of educational practice: I-L-A-P, which means: Initiative (need + motive) of a person or team - Localization (place of practice) - Activity to implement practice - Productivity (the effect of positive influence on the educational context). 
https://doi.org/10.15405/ejsbs.287

eISSN: 2301-2218 / Corresponding Author: Elena G. Tareva

Selection \& Peer-review under responsibility of the Editors

\section{Research Questions}

Several important questions are posed in this study:

3.1 How is the effectiveness of the educational practice determined?

3.2 What are the most progressive foreign language teaching practices?

3.3 Which practices need widespread dissemination in the context of digital education?

3.4 What are the difficulties of implementing educational practices in teaching foreign languages?

3.5 What recommendations can be made for teachers of foreign languages to update their practices?

\section{Purpose of the Study}

The purpose of the study is to consider the phenomenon of 'effective educational practices' and to present a set of successful practices for teaching foreign languages in the digital environment in the context of distance learning.

\section{Research Methods}

To study the problem of identifying effective educational practices, theoretical and practical research methods have been utilised in this investigation. Analytical and reflexive approaches relying on an analysis of literature on the problem covered in the paper, theoretical modeling of the classification of best education practices and an empirical survey of respondents followed by the statistical processing of the results.

The empirical portion of this study was based on a qualitative-explorative design. 48 semi-structured interviews were conducted with experienced teachers with 10-25 years of teaching experience from five universities in three Russian cities: Moscow, Saint-Petersburg and Perm. Semi-structured interviews were conducted.

DeJonckheere and Vaughn (2019) claim "this method typically consists of a dialogue between researcher and participant, guided by a flexible interview protocol and supplemented by follow-up questions, probes and comments" (p.1). The interview guide contained 28 questions about key strategies necessary to build an innovative economy and post-industrial society, arranged according to the principle "start with the simple questions and move to the complex ones". The open-ended questions contained assumptions about competencies that university graduates should have for successful professional socialization in the context of innovative production and the information society.

The answers to the questions were recorded (with the consent of the participants). The duration of the interview was not longer than 17 minutes. During the individual interview, 
https://doi.org/10.15405/ejsbs.287

eISSN: 2301-2218 / Corresponding Author: Elena G. Tareva

Selection \& Peer-review under responsibility of the Editors

additional clarifying questions were asked so that the interviewees could more accurately express their thoughts and opinions, enabling them to describe their position explicitly. The participants' responses were transcribed to identify vital information and a content analysis was performed to elicit the major themes that emerged in response to the research questions.

\section{Findings}

\subsection{The role of educational practices in foreign language teaching/learning}

The development of educational practices in teaching foreign languages is influenced by numerous factors. The factor of globalization has predetermined the setting of global requirements for the standards of foreign language training, which requires rethinking the application of practices related to selecting the goals and content of foreign language education. The constant change of technologies has necessitated a focus on the importance of nurturing the foreign language learners' creative abilities and their readiness to constantly improve their comprehension of a different culture. The growing need for the development and approval of advanced linguistic educational practices is also predetermined by the growing factor of online solutions and the development of "hybrid" pedagogies combining classroom work and online interaction that requires appropriate proficiency in a foreign language. The availability of open multi-user online courses like MOOCs and universities for billions (Coursera, EdX) have triggered the growth of non-systemic (non-formal) and informal education which presupposes the need to increase the level of proficiency in foreign language communication.

The efficacy of educational practices is also predetermined by a fundamental change in the thinking and consciousness of the younger generation who are 'digital', 'networked', and who interact with input through 'clip consciousness'. There is a noticeable increase in the individualized and pragmatic orientation of the value attitudes of young people, the deepening degree of introversion among students and a change in their orientations towards consumerism. It is no coincidence that more and more nominations such as 'generation why?' and 'Generation Z (Digital Natives)' are highlighted in media (Schroth, 2019). Hence, the emergence of the inevitable slogan - 'Pragmatic generation - pragmatic language!' implies the use of innovative practices of immersing students in the real-life contexts associated with their emotional and value background needs. What this means is that now, it is no longer the instructor who sets the content of foreign language education, chooses the forms, methods and means of its implementation in the learning situation, but the students themselves, implying 
https://doi.org/10.15405/ejsbs.287

eISSN: 2301-2218 / Corresponding Author: Elena G. Tareva

Selection \& Peer-review under responsibility of the Editors

that the students are ready for this kind of responsibility, to 'create their own destiny' in their educative journey.

The development of educational practices is an indispensable condition for improving foreign language education. New educational practices, new formats and means of research, innovation, and training can significantly change, enrich and transform reality at all levels of implementation of educational systems.

The development of educational practice is conditioned by the actual zone of technological development of education, which provides for the development of activities to a greater extent, in contrast to the mere acquisition of knowledge. Modern professional standards are built on the principle of listing the skills required to be applied in non-standard professional situations. As a result, new educational practices are required, which should rely exclusively on the cognitive and educational activity of the students themselves. The introduction of such technologies will ensure the transition from 'translational' pedagogy to a more 'activity' based one. This is supported by the growing role of knowledge management technologies, individualization of education and technologies of teamwork. When new educational practices are implemented, the education system will acquire the following key strategies necessary for an innovative economy and post-industrial society.

For the empirical portion of this qualitative-explorative study, 48 semi-structured interviews were conducted with instructors from five universities in three Russian cities: Moscow, Saint-Petersburg and Perm. The findings have several implications for study strategies in higher education institutions aiming at developing student competencies as well as deeper levels of knowledge (a projection up to 2020 is proposed). The data are presented in Table 1.

Table 1. Key strategies necessary for an innovative economy and post-industrial society

\begin{tabular}{lll}
\hline Key strategies & $\begin{array}{l}\text { Opinion of } \\
\text { respondents } \\
(\mathrm{n}=48)\end{array}$ & $\begin{array}{l}\text { Opinion of } \\
\text { respondents } \\
(\%)\end{array}$ \\
\hline $\begin{array}{l}\text { Basic training will be combined with a variety of opportunities } \\
\text { for continuing education and retraining }\end{array}$ & 32 & 66.66 \\
$\begin{array}{l}\text { Social characteristics of various educational routes will } \\
\text { converge / intersect, which in fact ensure the academic mobility } \\
\text { of students }\end{array}$ & 29 & 60.41 \\
$\begin{array}{l}\text { Ample opportunities for project work will ensure the } \\
\text { adaptability of students to a new social / professional } \\
\text { environment with its changeable characteristics and rapidly } \\
\text { changing needs }\end{array}$ & 25 & 52.08 \\
\hline
\end{tabular}


https://doi.org/10.15405/ejsbs.287

eISSN: 2301-2218 / Corresponding Author: Elena G. Tareva

Selection \& Peer-review under responsibility of the Editors

There will be an integration of education and industry in order to ensure joint work at the forefront of modern science

The proportion of independent work of students, the degree of their involvement in real research projects will be significantly increased

The system of educational consulting and support for life-long education will be widely developed

The competitiveness of Russian education, ready to generate

39.58 innovations, will be enhanced

\subsection{The role of educational practices in foreign language teaching/learning}

The presented tendencies, factors and projective forecasts make it possible to single out several directions (vectors) of the development of productive linguistic educational practices, which of course, are intersecting, but at the same time have their own 'zone of responsibility and sphere of influence'.

The first group contains practices that contribute to innovative modeling of teaching and research environment of an educational institution. This group includes practices aimed at:

- ensuring flexibility (due to modular organization) and intensity of the educational process to create and / or maintain educational mobility, including foreign;

- tutor support for students and educational navigation aimed at orienting individuals in the world around them, creating an awareness of and the means to satisfy their needs through the acquisition of foreign language communicative competence;

- implementation of international education programs: interuniversity student exchanges, study abroad in certain semesters and so on;

- the formation of an international educational-business professionally oriented environment: the creation of youth clubs, business clubs at the University (with the participation of people from different industries such as entrepreneurs, managers and experts);

- establishing project teams for research and development;

- expansion of opportunities, forms, means of network interaction at different levels of its implementation.

The second group includes linguistic 'immersion' practices that provide a contextual type of teaching foreign language communication. This group includes practices aimed at:

- the use of active and interactive education technologies: simulation and activity games, cases, projects, discussions, training with the help of simulators;

- inclusion of students in field research and development; 
https://doi.org/10.15405/ejsbs.287

eISSN: 2301-2218 / Corresponding Author: Elena G. Tareva

Selection \& Peer-review under responsibility of the Editors

- generation of new technologies of foreign language education;

- training on the principle of DIY (Do It Yourself), which involves the creation of educational content not for users, but by the users themselves; such practices contribute to an increase in the importance of technologies for the formation of new teaching aids, for example, 'open type' textbooks of a foreign language, created jointly with students or by students themselves;

- training of 'game-work' activities which presuppose a meaningful activity that goes beyond the usual opposition 'work - rest'. Such activities involve a combination of education, hobbies, and work activities.

A special focus in this system is given to linguistic practices, which focus on students' personal development. This group should include practices aimed at:

- launching the individual's own educational activity, his/her self-determination in terms of a personal challenge expanding the spheres of action of autonomy regarded as a personal quality;

- application of training technologies (simulators) for personal development: maintaining or changing identity, increasing self-awareness, motivation, improving self-organization, overcoming emotional burnout, ensuring resistance to professional deformation, etc.;

- taking into account the dynamics of the sociotype and genotype of learners of foreign language communication, such as age and gender factors;

- development / correction of special-needs students (inclusive practices, practices of working with gifted students, etc.);

- 'restart' for adults, mobilizing personal resources for education and re-launch of life and career path.

Finally, the fourth group should include information and communication technologies enhanced educational practices, which should embody:

- distance education technologies with wide use of the Internet (E-learning);

- screen technologies, interactive whiteboards, desks, tablets with access to global information networks;

- virtualization of education technologies through open universities;

- digital portfolio technologies;

- collective educational games technologies;

- mobile education / learning technologies;

- networking technologies; 
- smart environment technology based on the premise that any object in physical space will be present on the Web;

- 'Point of God' technology: as a result of the development of digital and mobile technologies, all digitizable information (including cultural heritage and descriptions of technologies) will be stored on the Web and will be available from anywhere in the world;

- cognitive technologies: information exchange on the principle of 'nervous system computer - network'; nano and biotechnology based on the consideration of the capabilities of the human nervous system.

Functioning in a complex interaction, these practices form a single system, the center (core) of which are practices focused on the development of the student's personality while other interconnected groups 'orbit' around this group, centripetally directed at the nuclear component.

\section{Conclusion}

Within the context of this study, the implementation of MOOCs within the blended learning format in higher education allowed instructors to cover the topics of the course extensively and systematically. The face-to-face teaching hours were utilised more effectively due to the integration of online lectures and tasks like a peer assessed essay being used from

To sum up, productive educational practices form the reality of the current stage in the development of education. Their appearance in the terminology system of General Didactics and Linguodidactics means a change in the leading trends coupled by the desire to strengthen the practical orientation of teaching procedures in order to promote the inclusion of innovations in the wider context of national education as soon as possible (if their productivity and effectiveness are confirmed). To implement productive educational practices, the following steps are required:

1) generating creative teams on a network basis for scientific and experimental determination of the potential of new educational practices and assessing the prospects and effectiveness of their implementation in the educational environment of the city, region or state;

2) determining the socio-economic factors for the success of the application and implementation of productive linguistic educational practices: internal factors (by clarifying and specifying the characteristics of educational practice) and external factors (through the recommended description of the environment in which this practice will work); 
3) developing a 'passport' of educational practice according to the parameters of its purpose, functionality, efficiency, usability, flexibility, modifiability, reliability, etc.;

4) anticipating the difficulties of introducing linguistic educational practice: identifying risk factors, unforeseen circumstances, removing unreasonable subjective value judgments, reducing the effect of 'resistance' to innovations, developing a willingness to embrace innovative thinking among participants in the educational process, etc.;

5) designing permanent internship sites operating on a network principle (experimental, large-scale, conveyor, etc.) specializing in the examination, assessment and dissemination of advanced educational practices;

6) ensuring the breadth and frequency of notifying the educational community about the results of the development, testing and promotion of new educational practices.

This study was conducted to identify the main trends in the field of innovative educational practices, the use of which will improve the quality of foreign language teaching. In the era of the COVID-19 pandemic, the actualization of such practices has become extremely needy. The follow-up studies should be aimed at identifying indicators of effectiveness of educational practices to determine the degree of their efficiency. It is also worth dwelling on the special competencies of a teacher who can apply innovative educational practices when teaching a foreign language within the scope of ever-increasing trends in digitalization.

\section{Acknowledgements}

The author(s) declare that there is no conflict of interest.

\section{References}

Arendale, D. (2010). What is a Best Education Practice? https://doi.org/10.13140/RG.2.2.24683.49442

Bessarabova, I. S., Bokova, T. N., \& Rychenkova, L. A. (2018). Goals and objectives of civic education in Russia and in the USA: The comparative analysis [Metas y objetivos de la educación cívica en Rusia y en Estados Unidos: Un análisis comparative]. Espacios, 39(38), 21.

DeJonckheere, M., \& Vaughn L. M. (2019). Semistructured interviewing in primary care research: a balance of relationship and rigour, Family Medicine and Community Health, 7(2), e000057. https://doi.org/10.1136/fmch-2018-000057

Gavrilyuk, O. A., Tareva, E. G., \& Lakhno, A. V. (2019). Investigating the association between university teachers' professional autonomy and their innovation performance [Universiteto dėstytojų profesinio savarankiškumo ir naujovių diegimo sąsajų tyrinėjimas] Pedagogika, 133(1), 128-148. https://doi.org/10.15823/p.2019.133.7 
Jhangiani, R. S., Hardin, E. E., \& Beers, M. J. (2019). Open Educational practices: Perceptions and outcomes, Psychology Learning \& Teaching, 18(1), 1-3. https://doi.org/10.1177/1475725718814354

Lanzara, G. (2016). Shifting Practices: Reflections on Technology, Practice, and Innovation. The MIT Press. https://doi.org/10.2307/j.ctt1b7x5sc

Makel, M. C., Hodges, J., Cook, B. G., \& Plucker, J. A. (2021). Both questionable and open research practices are prevalent in education research. Educational Researcher March 2021. https://doi.org/10.3102/0013189X211001356

Panke, S., \& Seufert, T. (2013). What's educational about open educational resources? Different theoretical lenses for conceptualizing learning with OER. E-Learning and Digital Media, 10(2), 116-134. https://doi.org/10.2304/elea.2013.10.2.116

Penalva, J. (2019). Contemporary methodological perspectives in educational research on 'teachers' practice': Assumptions and shortcomings for 'effective practices', European Educational Research Journal, 18(4), 61-482. https://doi.org/10.1177/1474904119830902

Penuel, W. R., Riedy, R., Barber, M. S., Peurach, D. J., LeBouef, W. A., \& Clark, T. (2020). Principles of collaborative education research with stakeholders: Toward requirements for a new research and development infrastructure, Review of Educational Research, 90(5), 627-674. https://doi.org/10.3102/0034654320938126

Prabakaran, M. (2020). Historical appropriation of epistemological values: A goal ahead for higher Education, Higher Education for the Future, 79(1), 67-81. https://doi.org/10.1177/2347631119886416

Purtik, H., \& Arenas, D. (2017). Embedding social innovation: Shaping societal norms and behaviors throughout the innovation process, Business \& Society, 58(5), 963-1002. https://doi.org/10.1177/0007650317726523

Schuster, J. R., \& Zingheim, P. K. (2013). Recalibrating best practice. Compensation \& Benefits Review, 45(3), 134-135. https://doi.org/10.1177/0886368713497547

Schroth, H. (2019). Are you ready for Gen Z in the workplace? California Management Review, 61(3)5-18. https://doi.org/10.1177/0008125619841006

Sen, S., Umemoto, K., Koh, A., \& Zambonelli, V. (2016). Diversity and social justice in planning education: A synthesis of topics, pedagogical approaches, and educational goals in planning Syllabi, Journal of Planning Education and Research, 37(3), 347358. https://doi.org/10.1177/0739456X16657393

Sterling, S. (2016). A Commentary on education and sustainable development goals, Journal of Education for Sustainable Development, 10(2), 208-213. https://doi.org/10.1177/0973408216661886

Tarc, P. (2019). Internationalization of education as an emerging field? A framing of international education for cross-domain analyses. Policy Futures in Education, 17(6), 732-744. https://doi.org/10.1177/1478210318824254

Traube, D. E., Begun, S., Okpych, N., \& Choy-Brown, M. (2016). Catalyzing innovation in social work practice. Research on Social Work Practice, 27(2), 134-138. https://doi.org/10.1177/1049731516659140 